\title{
Shale Stone and Fly Ash Landfill Use in Landslide Hazardous Area in Şırnak City with Foam Concrete
}

\author{
Yıldırım İ. Tosun \\ Mining Engineering Department, Engineering Faculty, Şırnak University, Şırnak, Turkey \\ Email: yildirimismailtosun@gmail.com
}

Received 18 July 2014; revised 16 August 2014; accepted 15 September 2014

Copyright (C) 2014 by author and Scientific Research Publishing Inc.

This work is licensed under the Creative Commons Attribution International License (CC BY).

http://creativecommons.org/licenses/by/4.0/

(c) (i) Open Access

\begin{abstract}
Şırnak City and the surrounding areas are on steeper slopes. There are sliding large land masses or rocks. Underground water and harsh climatic conditions contain high risk hazard areas in urban living site with higher population density. In order to eliminate landslides and related events, significant precautions should be taken. The mapping of landslide risk may ease to take precautions. Even the application of landfill rock may reduce water content of soil. In this research, fly ash and Mine Waste shale stone were used with low density foam concrete. Waste mixture at certain proportions decreased cement use. Shale stone as fine aggregate instead of fly ash in specific proportions improved mechanical strength and porosity. Hence landslide hazardous area could be safer for urban living.
\end{abstract}

\section{Keywords}

Foam Concrete, Landslide, Stability, Lightweight Aggregate

\section{Introduction}

In the developing countries, according to the topography of land in the mountainous areas, improper use of land increases the possibility of developing landslide. During earth excavations and constructions the landslide hazardous areas may not be considered [1]-[3].

Generally landslide hazardous area can be described as "possible sliding masses which make an angle with the surface" [4]-[6]. Slope stability and landslide problem dealing with the ground have been closely worked for many years by geotechnical engineers. For this reason, the deep disorder of land masses and slope stability, flood, are known as natural disasters such as hurricanes, similar to leading to serious loss of life and property 
[7]-[9]. With the increase of population growth there is a great need for the fields in long natural slopes. In these fields, people require some excavation, drainage precautions, different urban constructions, specific vegetation which can protect natural balance. However, the natural land mass stability can be concerned of the reasons such as heavy rains or earthquakes [10]-[13].

The civil engineers are much interested in the foundation issues regarding the earth soil, surface created by the nature, the slope geometry and design of the structures built on land [14]-[18]. The technological development parallel to the housing needs the high embankment, dams, large and deep excavations along with stability problems. Each year, few flood and landslide damages may cause to heavy loss of life. They also cause to loss of the millions of pounds in the world. The landslide in Turkey is one of the most important geotechnical hazards. Foam concrete produces much resistive low density porous structure in landfill by use of fly ash [19]-[23]. Fine aggregate with waste fly ash can improve strength in foam concrete [12] [24]-[27].

In this study, Şrnak city and the surrounding area were studied by geological mapping at 1/1000 scale and the soil units. The properties of every unit soil were determined. Landslide hazardous area provisionally was concerned in the first region's landslide area. The soil properties worked promotes the construction distributions in the future in Şırnak City, promoting winter tourism, one of the popular Southeastern Anatolian land. The importance of civil constructions under the threat of landslide intended to draw attention to the urbanization of the area.

In order to minimize the landslide hazard, geological and geotechnical analysis of the land slopes were needed to be studied. In this study, in the area of south Şırnak City (Figure 1) $2 \mathrm{~km}$ circled from the center of the slopes S2 was investigated as much critical hazardous area due to some mass sliding occurred in the district. Geotechnical properties soils of four different locations were determined for examining the stability analysis. This project was carried out foam concrete application for hazardous landslide area for urban use, which will open workspace and environment covering the foundations and stabilities of civil engineering construction in the field of $4 \mathrm{~km}^{2}$ area. The laboratory studies followed by the polar coordinate system using a field study with the topographic maps and cross-sections of four slopes were prepared. Landfills with foam concrete were applied on the research site.

\section{Geology of the Şırnak City Province}

Southeastern Anatolian Region has certain tectonic structures and stratigraphy containing the fault system and especially tension cracks along the ground to the depths. Underground waters, geothermal energy fluids flow the deep formations [28]-[30]. North-south direction across the region with the effect of compression of the earth's crust has been subjected to a stretching east-west direction, and the resulting tension cracks along the earth have risen from the olivine magma.

Alluvium, dissociated limestone in the recent study area of Şırnak City (Figure 2) is distributed among the alluvial deposits of the neighborhood. There are the limestone gravels in the area and very well rounded pebbles

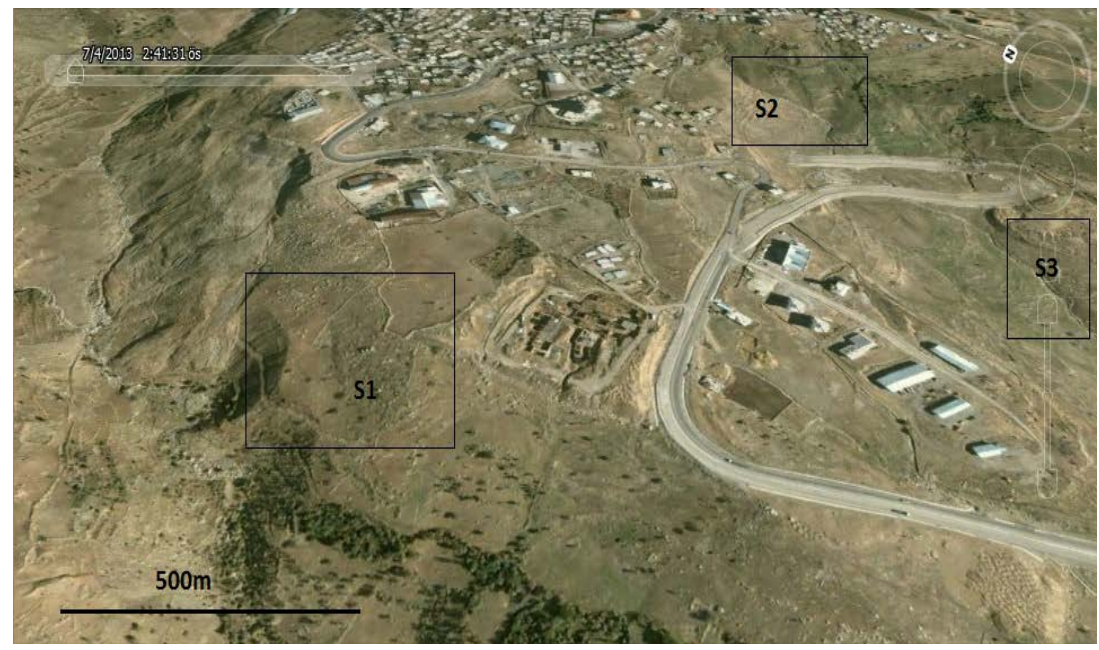

Figure 1. Satellite image of the study area and the slopes in Şirnak City. 


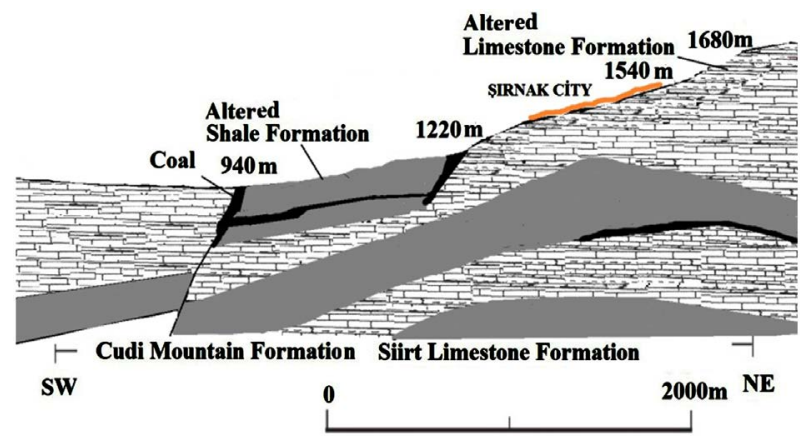

Figure 2. The geologic cross-section of the Şirnak City.

associated with soil. Alluvium soil, marly shale occurs in wide urban living area of Şırnak City at the south, which field as seen in Figure 1 extends to the study area. In field observations, the Miocene aged limestone and dissociated limestone were determined. Thickness of this formation is highly variable among $2-30 \mathrm{~m}$. Decrease in the slope of the land shows that a relatively small outcrop occurs.

Southwestern limestone is moderately dissociated due to the deteriorated rock formations into the layers. Due to the resistance, large parts of rock at $50 \%-90 \%$ rate are different. The cracks on the surface of the rocks are dominated by brown and blackish color. In the study area, the cross-section (Figure 2) shows the extent of moderately, or highly dissociated formation along the valley portion. In those regions, the separated segments of the shale are observed.

The study area to the north of the city contains fundamentally higher land slopes in the urban location. The observations of sorting and grading of seen alluvial fill show a thickness varies between $10-35 \mathrm{~m}$. The high slope massive fills are concerned as active and potential hazardous landslide areas and are requiring for various examinations.

\section{Geotechnical Properties}

The representative contents of drilling logs were taken from the rectangular fields as seen from Figure 1. The representative samples of soil were taken from each different location over the slopes. The experiments conducted to determine the geotechnical characteristics regarding the Turkish Standards and American Standards (ASTM 3080) [31]-[33]. Regarding the logs of wells of 58 m, $135 \mathrm{~m}, 60 \mathrm{~m}, 574 \mathrm{~m}$ wells, the mechanical properties of soils are given in Table 1.

In the study area of fine-grained portions of alluvium samples were taken from slopes as undisturbed and disturbed sample logs. The results of the experiments conducted on the samples of disturbed soil grain distribution curve, unit weight and consistency limit grain sizes are given in Table 1.

With the help of Shear box tests on undisturbed samples, the effective cohesion (c') and effective shear resistance angle $\left(\phi^{\circ}\right)$ belonging to the representative logs was found. TS standard and ASTM standards were used [33]. During carrying out this experiment, the bulk density of the material, and the void ratio were determined with compression amount. Plastic and liquid limit results obtained in the experiments for each sample are given in Table 1. According to the classification of the soils in S1 and S2 landslide hazardous areas, the soils were determined as less plastic and non plastic group, even the soils of S3 and S4 in the landslide hazardous area were determined as less plastic.

\section{Results and Discussion}

\subsection{Foam Concrete Landfill}

Fly ash and Mine Waste Shale stone thrown as waste in Şırnak City of Turkey were used with foam concrete. Waste mixture at certain proportions of fly ash and shale stone were decreasing the use of cement. Fine shale aggregate in specific proportions were decreasing the use of fly ash. Certain proportion of fly ash and fine shale aggregate mixture used improved mechanical strength and porosity. Fine aggregate was reducing porosity rather than fly ash. Three different methods are performed in foam concrete production. Firstly, only foam concrete was used as binder of mixture fill. Secondly, foam concrete included fly ash. Thirdly, foam concrete included fly 
Table 1. Properties soil formation in Şirnak City.

\begin{tabular}{|c|c|c|c|c|}
\hline Spec No. & S1 & S2 & S3 & S4 \\
\hline Level (m) & 1225 & 1221 & 1233 & 1227 \\
\hline Wopt, \% & 15.9 & 13.7 & 10.8 & 11.4 \\
\hline $\mathrm{c}^{\prime}(\mathrm{kPa})$ & 1.2 & 4.7 & 5.3 & 2.5 \\
\hline$\phi^{\prime}$ & 12.5 & 22.5 & 21 & 20 \\
\hline $\mathrm{L}_{1}(\%)$ & 26 & 15 & 28 & 17 \\
\hline $\mathrm{P}_{1}(\%)$ & 19 & 11 & 18 & 22 \\
\hline Ip (\%) & 10 & 9 & 8 & 12 \\
\hline$\gamma_{\text {sat }} \mathrm{g} / \mathrm{cm}^{3}$ & 2.4 & 2.5 & 2.4 & 2.3 \\
\hline$\gamma_{\text {ap }} \mathrm{g} / \mathrm{cm}^{3}$ & 1.65 & 1.6 & 1.78 & 1.6 \\
\hline$\gamma_{\text {dry }} \mathrm{g} / \mathrm{cm}^{3}$ & 1.82 & 1.76 & 1.9 & 1.7 \\
\hline$\gamma_{\mathrm{s}} \mathrm{g} / \mathrm{cm}^{3}$ & 2.02 & 1.84 & 2.0 & 1.8 \\
\hline Spec. No. & S11 & S22 & S31 & S41 \\
\hline$\gamma_{\max } \mathrm{g} / \mathrm{cm}^{3}$ & 1.68 & 1.67 & 2.05 & 1.90 \\
\hline $\mathrm{w}_{\mathrm{opt}} \%$ & 15.9 & 15.8 & 12.3 & 13.0 \\
\hline Permeability (k) (mD) & 0.56 & 0.38 & 0.31 & 0.56 \\
\hline
\end{tabular}

ash and fine shale stone. Effects of foam concrete on mechanical properties of fly ash and fine shale stone aggregate were studied intensively. Uniaxial and triaxial compression strengths of foam concrete landfills were tested in the laboratory ELE type press [26] [33].

Another purpose of this study was to improve the ready-mixed foam concrete industry, and beneficiation from Şırnak Coal Mine Waste shale stone and fly ash. The results contributed the widely efficient use of high amount of shale stone and fly ash, better workability of the foam concrete and the improved curing time. For this purpose, in the mixture of foam concrete fine shale aggregate was added $5 \%, 10 \%, 20 \%$ and $30 \%$ weight rates, fly ash was added $5 \%, 10 \%, 20 \%$ and $30 \%$ weight rates, respectively. Water/cement ratio were kept constant $3 / 1$ $4 / 1$ volume rate. The prepared laboratory $10 \times 10 \times 10 \mathrm{~cm}$ cubic blocks was tested as the foam concrete mixture blocks. In conclusion, depending on the amount of the fly ash in foam concrete mixture, workability significantly improved and even significant the pressure increase was observed.

Compression strength values depending on the increasing amount of fly ash and foam concrete reduced. Increase in fly ash amount used in the foam concrete mixture by curing time was found to reduce the porosity.

The representative rock fill samples were taken from the construction foundation and strengths with the bulk density are shown in Table 2. For determination of rock types based on logging were carried out and the results showed poor and good rock classification as given in Tables 2-4.

In this study, coarse shale stone over $10 \mathrm{~cm}$ sizes as rock fill in the foundation and with foam concrete was used. The strength and the mechanical parameters of addition of rock fill at $10 \%$ weight rate as shale stone into the foam concrete were investigated. The results of those blocks are given in Table 3 . The amount of fly ash on properties of water discharges in the landslide risk area were also investigated and briefly given in Table 4.

\subsection{Procurement of Slopes with the Foam Concrete}

Evaluation of the test results to determine the level of soil permeability regarding Table 1, S1, S2, S3 and S4 slopes may be critically hazardous on land constructions. It is observed that low permeable ground under construction as seen in Figure 3 caused sliding tension cracks and soil land slide.

Landfill of foam concrete performed was compared with the soil samples taken from the test results are given in Table 2. The pore pressure parameters foam concrete landfill at the optimum water content and maximum dry 


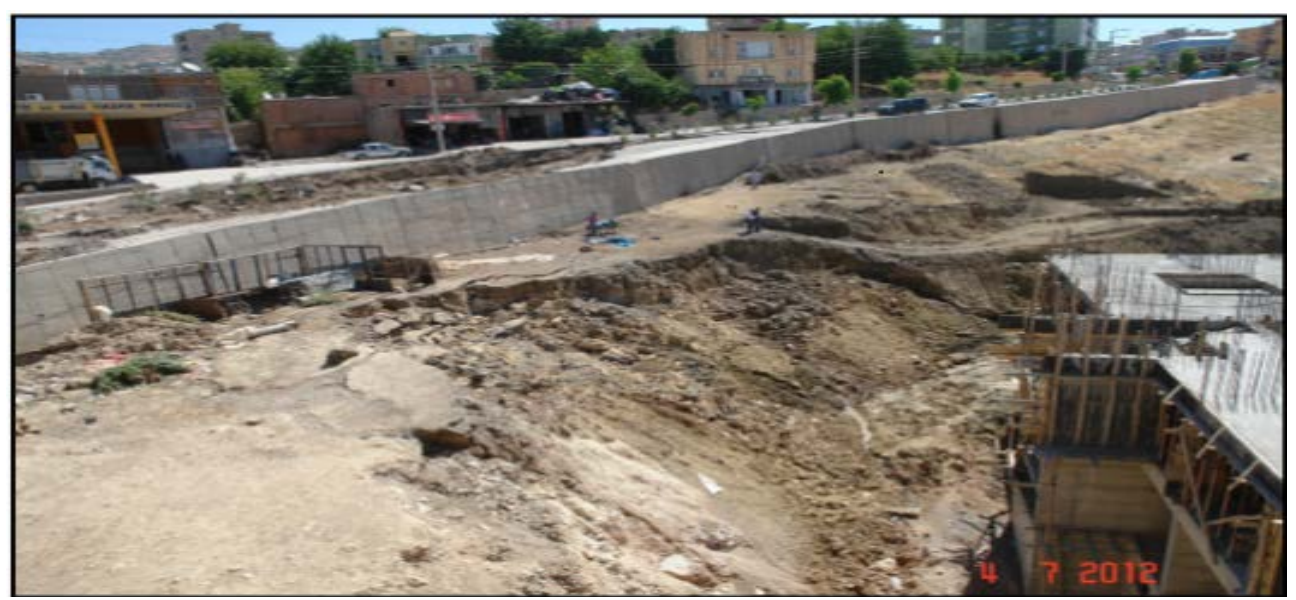

Figure 3. S2 study area, construction work and sliding land soil and foam concrete landfill study area.

Table 2. The drilling data and calculated rqd by rmr rock classification parameters.

\begin{tabular}{ccccc}
\hline Depth (m) & Drill Log (\%) & RQD & RMR & Rock Quality \\
\hline $0.3-1.5$ & $69.3-78.9$ & $53.3-67.2$ & 68 & Good \\
$1.5-3.0$ & $58.4-90.2$ & $50.6-78.5$ & 63 & Good \\
$3.0-4.5$ & $84.5-97.5$ & $56.9-83.4$ & 62 & Good \\
$4.5-6.0$ & $96.1-94.3$ & $44.2-90.9$ & 47 & Weak \\
$6.0-7.5$ & $94.6-96.9$ & $43.9-45.3$ & 47 & Weak \\
$7.5-9.0$ & $15.5-25.0$ & $48.1-43.7$ & 44 & Weak \\
$9.0-10.5$ & $16.4-22.0$ & $49.4-46.2$ & 44 & Weak \\
$10.5-12.0$ & $96.3-98.2$ & $47.4-45.3$ & 44 & Weak \\
\hline
\end{tabular}

Table 3. The mechanical parameter values of foam concrete landfill.

$\begin{array}{cc}\text { Natural Unit Weight } \gamma_{\mathrm{n}}\left(\mathrm{g} / \mathrm{cm}^{3}\right) & 1.21 \\ \text { Saturated Unit Weight } \gamma_{\mathrm{d}}\left(\mathrm{g} / \mathrm{cm}^{3}\right) & 1.44 \\ \text { Cohesion, c (kPa) } & 135 \\ \text { Internal Friction Angle, } \varphi\left({ }^{\circ}\right) & 34\end{array}$

Table 4. The parameters and the resulting strength of foam concrete landfill.

\begin{tabular}{cccc}
\hline Mixture in Foam Concrete & $\sigma$, Strength MPa & Water Discharge (\%) & $\gamma_{\text {ap }}$ Unit Weight, g/cm \\
\hline Shale Stone, 5\% & $8.9-9.9$ & 88.2 & 1.540 \\
$10 \%$ & $12.4-13.9$ & 85.5 & 1.620 \\
$20 \%$ & $14.5-17.5$ & 82.4 & 1.790 \\
$30 \%$ & $19.1-20.3$ & 77.7 & 1.850 \\
Fly Ash, 5\% & $9.6-9.9$ & 64.3 & 1.250 \\
$10 \%$ & $11.5-12.5$ & 62.7 & 1.380 \\
$20 \%$ & $13.4-13.9$ & 61.2 & 1.420 \\
$30 \%$ & $14.3-14.9$ & 60.3 & 1.580 \\
\hline
\end{tabular}


unit weight are given in Table 3. The determined values were used in the calculation of the stability of slopes. A natural slope does not affect the stability of the compression parameters. These parameters of the soil were improved by compacted landfill in the desired manner. Artificial compression parameters used directly on the slopes. If there is a risk of landslide hazard in a natural layer, compression case using these parameters are used in stability analysis. The use of anchorage or pile applications should be taken in consideration against to the any possible hazard of landslide in the front slope or the slope should be gradually compacted. In this study, an amount of the natural ground is excavated and compressed and foundation was filled by certain foam concrete and rock fill. The pore parameters were improved against to the hazard. In this case, the stability analysis of these improved parameters was used in the stability analysis of compressed ground.

$c^{\prime}$ and $\phi$ ' values are taken as given in Table 3, respectively. In addition, the safety coefficient values were used as 1.3 - 1.5 in GEO5 program. The probable circular sliding surfaces were determined using the methods such as landslide, according to Fellenius, Bishop and Janbu calculations [34]-[36].

This kind of soil conditions in this study provide a circular or non-circular sliding close quarters to the top of the slope begin as a deep developing and ongoing planar surfaces. In these type of instabilities developed along the sliding surface in order to investigate the stability of the slope the Bishop method is commonly used [37][39].

At the construction site foundation the foam concrete wells in $2 \mathrm{~m}$ diameters were excavated at elevation 1210 $\mathrm{m}$ to $10 \mathrm{~m}$ depth to sliding face. At creeping slopes hazard of mass slide may be prevented by rock fill. Even 1 meter depth foam concrete landfill horizontal columns constructed as seen in Figure 4.

With performed the foam concrete landfill application as constructed in Figure 4, hydraulic works at high rate water discharge through the foam concrete structure of landfill, even separately improved compression strength obtained by waste shale stone and fly ash use. Shale stone in the foam concrete mixture provided higher water discharges as given in Table 4. According to landfill construction seen from the Figure 5, the landfill length varies from 3 to $10 \mathrm{~m}$ horizontal length. Shale stone and fly ash concrete covered foam concrete tunnels and wells could easily provide the sliding face dry.

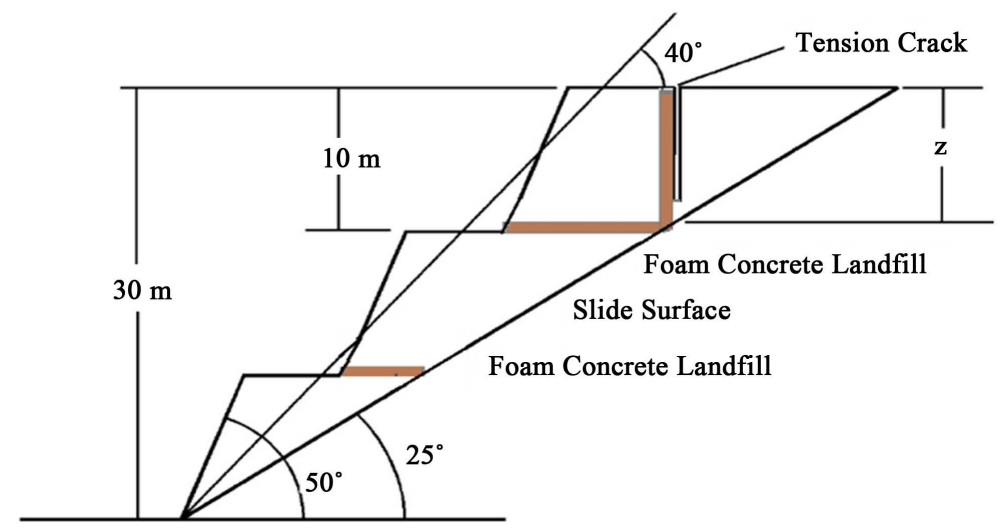

Figure 4. S2 Study area, foam concrete landfill application cross-section on hazardous landslide area.

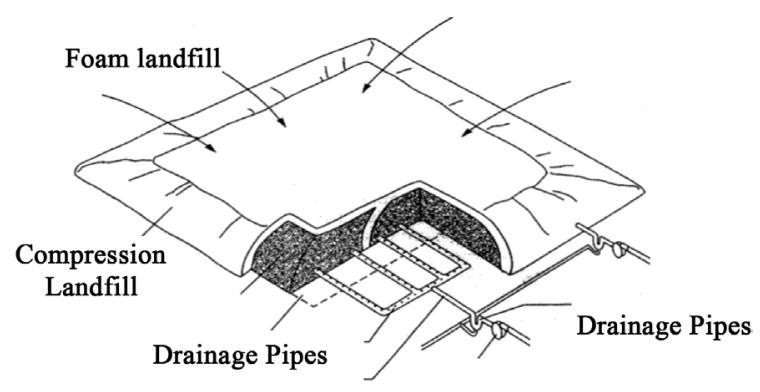

Figure 5. Construction foam concrete landfill application on hazardous landslide area. 
The landslide S2 maximum elevation difference between the top and the heel point $35 \mathrm{~m}, 30$ m maximum height of the slope divided three faces by excavation, surface slope angle is $43^{\circ}$. Any slope in the floor was too weak, rock fill mass covered weak material properties of the slope along so that circular $10 \mathrm{~m}$ mass sliding was avoided. However water drainage was almost varied. At that point, the ground-rock interface with a certain water holding structural feature needed the foam concrete application so that in the mass, reaching low shear strength planar levels were auger bored and tunneled and foam concrete -rock fill were applied as seen in Figure 5 .

\subsection{Investigation of Mass Movement and Slope Stability Analysis}

In this study, the compression strength of the foam concrete applied landfills for the slopes in the area is illustrated in Figure 6. The stability analysis for S2 slope in terms of active and potential hazardous areas of landfill was carried out. The applied foam concrete on the soil surface improved the strength and eliminated hazard of sliding. According to studies of the stability without landfill, the land mass slope area there was relative movement designated as the active landslide area. Relative movements are determined by making use of tension cracks on the surface.

Belonging to the limit equilibrium factor of safety of slopes drawn in accordance with different sliding surfaces for the Bishop in GEO5, with the circular shift diagram Janbu and Fellenius methods showed over 1.3 safety factors. In the field the observed tension cracks showed the active movement. In the case of foam concrete landfill, the intrinsic parameters of the sliding surface will appear smaller than those safety values found with the parameters in the soils without the landfill. It is clear that safety value was between 1.5 and 1.8 with the landfill as seen from Figure 7. From this point of view, the foam concrete landfill of horizontal column improved

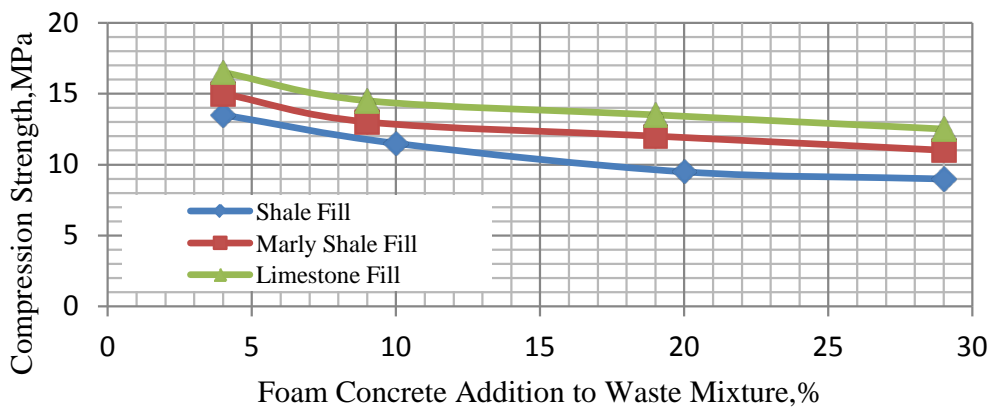

Figure 6. Compression strength of foam concrete landfill on hazardous landslide area.

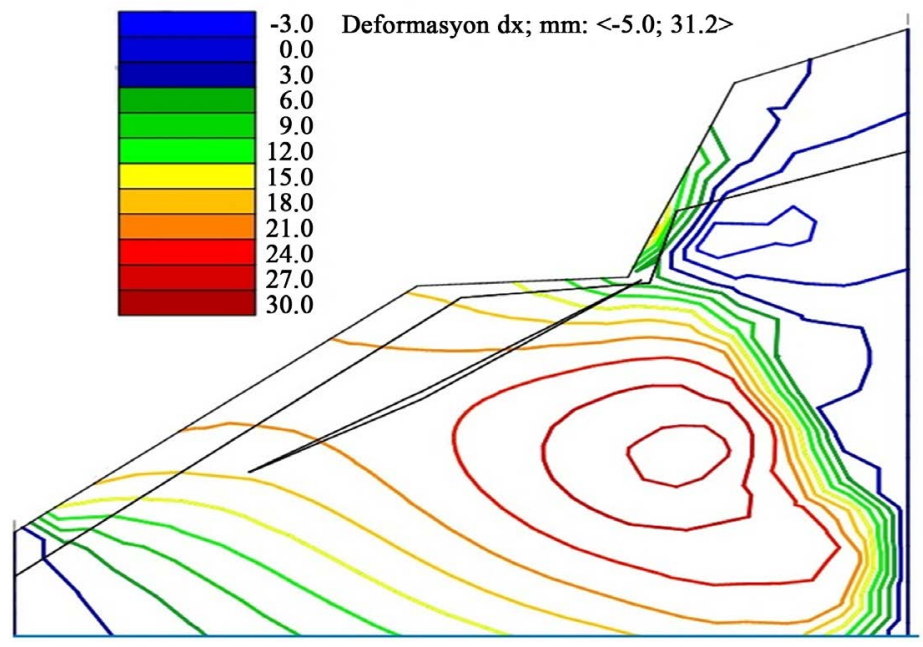

Figure 7. Slope stability, deformation values of foam concrete landfill on hazardous landslide area. 
water level under sliding surfaces and the safety factor values reached over 1.8 from instable value of 1.3. Deformation displacements at $\mathrm{x}$ axis showed hazardous levels of $30 \mathrm{~mm}$ under the level of the ground water table and the sliding surface. However, over the sliding surface that displacement value remained very low 6 - $9 \mathrm{~mm}$ secured level.

\section{Conclusions}

Şırnak City located within the boundaries of four separate hill slopes and slope stability of soil samples should be taken from the site under construction. The geological and geotechnical properties investigated by field studies and laboratory experiments showed less plastic soil formations keeping water pore pressures.

Alluvium (Miocene), dissociated shale (Miocene) and the dissociated limestone (Miocene) are ranked propagating landslide hazardous manner of high slopes under construction sites.

The studied area of potential landslide hazard around the active site of stress, cracking displacement of relative motion could be observed, but changed regarding the field.

Soil samples performed on the laboratory test result in the slope material permeable that the cohesion value of 1.2 - $4.7 \mathrm{kPa}$, angle of internal friction of the $17.5^{\circ}-22.4^{\circ}$ varied between unified soil classifications. Stability analysis performed in the light of this information, S1, S2 and S3 were unstable hillsides. By using foam concrete application, the hazardous slopes were concluded the stable condition. Various researches on foam concrete showed porous structure and advantageous points in concrete structures by use of fly ash.

As a result of the terrain views, especially in the months of May and June by the melting snow stream flow increase seen in the severe erosion of the slope formed on the heel and this effect was determined to have a negative impact on slope stability. Landfill material, or rock material or stream should be investigated and varied in water discharge effect.

In the experiments for different slope inclinations, especially in low-slope slope (1/1), very high security numbers (such as s2.0) were obtained. Therefore, by increasing the slope of the land slope stability calculations should be renewed. Slope safety number began to decrease with increasing safety and below 1.3 (approximately over $50^{\circ}$ ) slope inclinations.

Rocky slope stability analysis done for the ground, rocky land, which had been dissociated from the floor to act differently, next to the sliding movement of the rock fall incidents, such as being able to vary hazardous parameters. In the rocky terrain of slope stability analysis in order to solve problems with similar method of landfill may not be sufficient, however as a specially crafted construction works should be used.

High strength landfill mass improved the slope stability. However, low strength foam concrete landfill might result in higher water discharge and drier soil condition.

Plants, rain water infiltration into the mass simplifies and reduces water runoff and cause land sliding. This is an obstacle to the erosion of the mass. Reaching deep into the roots of the plants roots improves the mechanical balance of the masses.

Landfill porosity thus reduces the retaining force which stabilizes the slopes. For this reason, the vegetation of landslide hazardous areas is preventive enrichment an important parameter in the region. However, up to $30 \mathrm{~m}$ depth to the sliding surfaces of vegetation stability effect will be minimal. Weathering of rocks varies greatly into undergo, to the weakening of the bond between grains and leads to total extinction. In the study area weakened by weathering rocks are easily eroded and slope angle of inclination of the slope is changing with height. Dissociation observed in rocks in the study area also offers a negative contribution to stability problems.

For those reasons, geotechnical engineer can use virtual any classical slope stability programs, rock slope stability calculations in order to do construction safety.

As a result of this work performing of the geotechnical analysis, hazardous conditions would not be expected of a very large landslide. However, the urban living areas and the urban development areas at certain land slopes for the possibility of landslide hazard should need further technological improvements.

\section{Acknowledgements}

The author would like to thank Mining Engineering Department of Süleyman Demirel University.

\section{References}

[1] Bishop, A.W. (1955) The Use of the Slip Circle in the Stability Analysis of Earth Slopes. Geotechnique, 5, 7-17. http://dx.doi.org/10.1680/geot.1955.5.1.7 
[2] Cernica, J.N. (1995) Geotechnical Engineering: Soil Mechanics. John Wiley and Sons Inc., Canada.

[3] Das, B.M. (1994) Principles of Geotechnical Engineering. PWS Publishing Company, USA.

[4] Dramis, F. and Sorriso-Valvo, M. (1994) Deep-Seated Gravitational Slope Deformations, Related Landslides and Tectonics. Engineering Geology, 38, 231-243. http://dx.doi.org/10.1016/0013-7952(94)90040-X

[5] Höek, E. (1970) Estimating the Stability of Excavated Slopes in Opencast Mines. Institution of Mining and Metallurgy, A105, A132.

[6] Höek, E. and Bray, J.W. (1977) Rock Slope Engineering. Stephen Austin and Sons Ltd., Hertford.

[7] Hoek, E. (2013) Practical Rock Engineering. Hoek Notes by Evert Hoek. http://www.rocscience.com

[8] Hutchinson, J.N. (1995) Landslide Hazard Assessment. Keynote Paper. In: Bell, D.H., Ed., Landslides, Proceeding of 6th International Symposium on Landslides, Christchurch, Vol. 1, Balkema, Rotterdam, 1805-1841.

[9] Lambe, W.T. and Whitman, R.V. (1969) Soil Mechanics. John Wiley and Sons, New York.

[10] Langan, B.W., Weng, K. and Ward, M.A. (2002) Effect of Silica Fume and Fly Ash on Heat of Hydration of Portland Cement. Cement and Concrete Research, 32, 1045-1051. http://dx.doi.org/10.1016/S0008-8846(02)00742-1

[11] Paşamehmetoğlu, A.G., Özgenoğlu, A. and Karpuz, C. (1991) Rock Slope Stability. 2nd Edition, T.M.M.O.B Mining Engineering Bureau Publisher, Ankara.

[12] Park, C.K., Noh, M.H. and Park, T.H. (2005) Rheological Properties of Cementitious Materials Containing Mineral Admixtures. Cement and Concrete Research, 35, 842-849. http://dx.doi.org/10.1016/j.cemconres.2004.11.002

[13] Bouzoubaa, N., Bilodeau, A., Sivasundaram, V., Fournier, B. and Golden, D.M. (2004) Development of Ternary Blends of High-Performance Concrete. ACI Materials Journal, 101, 19-29.

[14] Chindaprasirt, P., Homwuttiwong, S. and Sirivivatnanon, V. (2004) Influence of Fly Ash Fineness on Strength, Drying Shrinkage and Sulfate Resistance of Blended Cement Mortar. Cement and Concrete Research, 34, 1087-1092. http://dx.doi.org/10.1016/j.cemconres.2003.11.021

[15] Hussin, M.W. and Awal, A.S.M.A. (1996) Palm Oil Fuel Ash-A Potential Pozzolanic Material in Concrete Construction. Proceedings of the International Conference on Urban Engineering in Asian Cities in the 21st Century, Bangkok, 20-23 November 1996, D361-D366.

[16] Isaia, G.C., Gastaldini, A.L.G. and Moraes, R. (2003) Physical and Pozzolanic Action of Mineral Additions on the Mechanical Strength of High-Performance Concrete. Cement and Concrete Composites, 25, 69-76. http://dx.doi.org/10.1016/S0958-9465(01)00057-9

[17] Kiattikomol, K., Jaturapitakkul, C., Songpiriyakij, S. and Chutubtim, S. (2001) Study of Ground Coarse Fly Ashes with Different Finenesses from Various Sources as Pozzolanic Materials. Cement and Concrete Composites, 23, 335343. http://dx.doi.org/10.1016/S0958-9465(01)00016-6

[18] Kim, H.K., Jeon, J.H. and Lee, H.K. (2012) Workability, and Mechanical, Acoustic and Thermal Properties of Lightweight Aggregate Concrete with a High Volume of Entrained Air. Construction and Building Materials, 29, 193200. http://dx.doi.org/10.1016/j.conbuildmat.2011.08.067

[19] Chen, X., Yan, Y., Liu, Y.Z. and Hu, Z.H. (2014) Utilization of Circulating Fluidized Bed Fly Ash for Preparation of Foam Concrete. Construction and Building Materials, 54, 137-146. http://dx.doi.org/10.1016/j.conbuildmat.2013.12.020

[20] Ranjani, G.I.S. and Ramamuthy, K. (2012) Behaviour of Foam Concrete under Sulphate Environments. Cement \& Concrete Composites, 34, 825-834. http://dx.doi.org/10.1016/j.cemconcomp.2012.03.007

[21] Liu, M.Y.J., Alengram, U.J., Jumaat, M.Z. and Mo, K.H. (2014) Evaluation of Thermal Conductivity, Mechanical and Transport Properties of Lightweight Aggregate Foamed Geopolymer Concrete. Energy and Buildings, 72, $238-245$.

[22] Xia, Y.Q., Yan, Y. and Hu, Z.H. (2013) Utilization of Circulating Fluidized Bed Fly Ash in Preparing Non-Autoclaved Aerated Concrete Production. Construction and Building Materials, 47, 1461-1467.

[23] Sata, V., Jaturapitakkul, C. and Kiattikomol, K. (2007) From Pozzolan of Influence on Mechanical Properties of Various By-Product Materials High-Strength Concrete. Construction and Building Materials, 1589-1598.

[24] Moulien, M. and Khelafib, H. (2008) Performance Characteristics of the Lightweight Aggregate Concrete Containing Natural Pozzolan. Building and Environment, 43, 31-36.

[25] Demirbog, R., Orung, I. and Rose, R. (2001) Effects of Expanded Perlite Aggregate and Mineral Admixtures on the Compressive Strength of Low-Density Concretes. Cement and Concrete Research, 31, 1627-1632.

[26] Chen, B. and Liu, J.Y. (2008) Application of Experimental in Lightweight Concrete Admixtures with Mineral High Strength and Workability. Construction and Building Materials, 22, 655-659.

[27] Anderson, M.G. and Richards, K.S. (1982) Slope Stability. John Wiley and Sons Ltd., New York.

[28] Anonymous (2013) GEO5_Engineering Manuals_Part 1, Part 2. http://www.finesoftware.eu/geotechnical-software/ 
[29] Anonymous (2009) GEO5-FEM-Theoretical Guide. http://www.finesoftware.eu/geotechnical-software/

[30] Anonymous (2012) Şırnak City Bureau Reports. Şırnak.

[31] ASTM (1990) Standard Test Method for Direct Shear Test of Soils under Consolidated Drained Condition. West Conshohocken, D3080-90.

[32] ASTM (1985) Standart Specifications for Fly Ash and Raw or Calcined Natural Puzzolan for Use as Mineral Admixture in Portland Cement Concrete. ASTM, Philadelphia, ASTM C 618-85.

[33] ASTM (1999) Standard Test Method for Time of Setting of Concrete Mixtures by Penetration Resistance. Pennsylvania, ASTM C 403.

[34] Görög, P. and Török, Á. (2006) Stability Problems of Abandoned Clay Pits in Budapest. IAEG2006 P295, The Geological Society of London, London.

[35] Görög, P. and Török, Á. (2007) Slope Stability Assessment of Weathered Clay by Using Field Data and Computer Modeling: A Case Study from Budapest. Natural Hazards and Earth System Sciences, 7, 417-422. www.nat-hazards-earth-syst-sci.net

[36] Pruška, J. (2009) Comparison of Geotechnic Softwares-Geo FEM, Plaxis, Z-Soil. In: Vanícek, et al., Eds., XIII ECSMGE, Vol. 2, CGtS, Prague.

[37] Sata, V., Jaturapitakkul, C. and Kiattikomol, K. (2007) Influence of Pozzolan from Various By-Product Materials on Mechanical Properties of High-Strength Concrete. Construction and Building Materials, 21, 1589-1598.

[38] Vaneckova, V., Laurin, J. and Pruska, J. (2011) Sheeting Wall Analysis by the Method of Dependent Pressures. Geotech, Hanoi, 7.

[39] Wiley, L. (1987) Slope Stability Geotechnical Engineering and Geomorphology. England.

\section{Nomenclature}

c': kPa : Effective cohesion

$\phi$ : degree: Effective angle of internal friction

$\sigma$ : MPa: Compression strength

Ip: Plasticity index

$\mathrm{L}_{1}$ : Liquid limit

$\mathrm{P}_{1}$ : Plastic limit

$\mathrm{W}_{\text {opt: }}$ Optimum water content

$\gamma_{\text {ap }} \mathrm{g} / \mathrm{cm}^{3}$ : Apparent unit weight

$\gamma_{\text {sat }} \mathrm{g} / \mathrm{cm}^{3}$ : Saturated unit weight

$\gamma_{\text {dry }} \mathrm{g} / \mathrm{cm}^{3}$ : Dry unit weight

$\gamma_{\max } \mathrm{g} / \mathrm{cm}^{3}$ : Maximum dry unit weight

$\gamma_{\mathrm{s}} \mathrm{g} / \mathrm{cm}^{3}$ : Grain unit weight

$\mathrm{k} \mathrm{mD}$ : Coefficient of permeability

s: Safety factor

S1: No. 1, the landslide hazardous slope

S11: Soil samples taken from No. 1, the landslide hazardous slope zone

SP: Unified soil classification; worst-graded sands, gravelly sands, little or no fines

SW: Unified soil classification; well graded sands, gravelly sands, little or no fines

SC: Unified soil classification; clayey sand, sand-clay mixture

GW: Unified soil classification; well-graded gravel, gravel-sand mixtures, little or no fines 
Scientific Research Publishing (SCIRP) is one of the largest Open Access journal publishers. It is currently publishing more than 200 open access, online, peer-reviewed journals covering a wide range of academic disciplines. SCIRP serves the worldwide academic communities and contributes to the progress and application of science with its publication.

Other selected journals from SCIRP are listed as below. Submit your manuscript to us via either submit@scirp.org or Online Submission Portal.
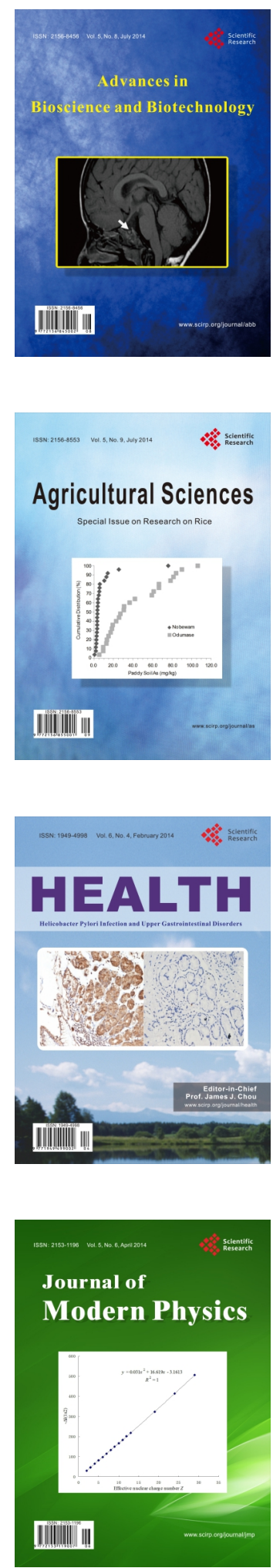
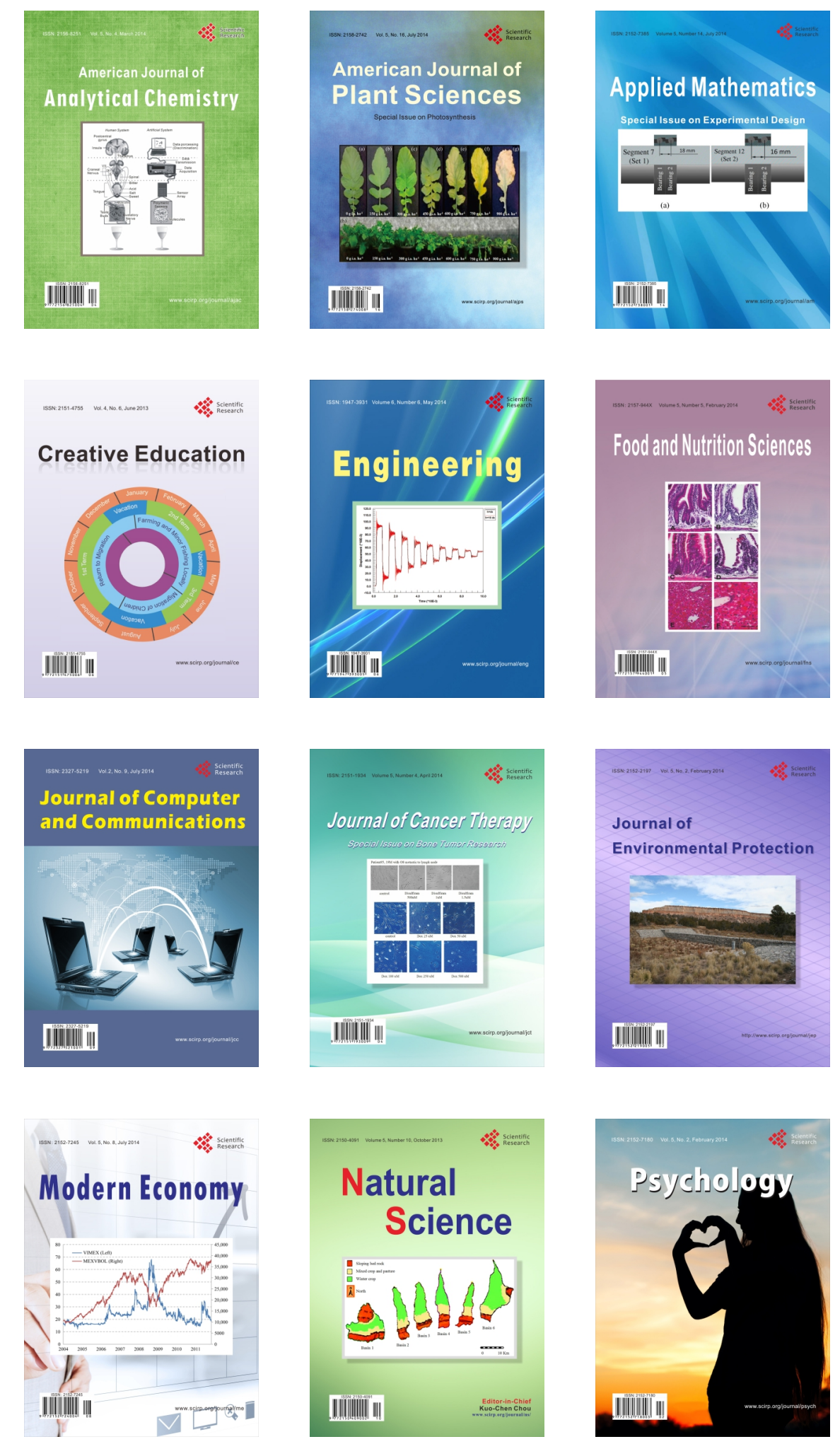